РАЗОВ Павел Викторович - доктор социологических наук, доцент; профессор департамента социологии, истории и философии Финансового университета при Правительстве РФ (125993, Россия, 2. Москва, Ленинградский пр-кт, 49; PVRazov@fa.ru

АМЕРСЛАНОВА Айнара Надировна - старший преподаватель департамента учета, анализа и аудита, начальник отдела программ развития Финансового университета при Правительстве РФ (125993, Россия, г. Москва, Ленинградский пр-кт, 49; Aynarana@gmail.com)

\title{
ОЦЕНКА КАЧЕСТВА И ВОСТРЕБОВАННОСТИ ОБРАЗОВАТЕЛЬНЫХ УСЛУГ ВЫСШИХ УЧЕБНЫХ ЗАВЕДЕНИЙ С УЧЕТОМ МНЕНИЯ ПОТРЕБИТЕЛЕЙ
}

Аннотация. В статье рассматривается оценка востребованности и качества образовательных услуг, предоставляемых вузами, которая осуществляется на основе специально разработанной методики. Эта методика представлена в форме алгоритмизированной модели организационно-технологического характера, которая включает общие этапы научного исследования и специфические процедуры выявления конкурентоспособности (рыночной ценности) образовательных организаций.

Ключевые слова: качество образовательных услуг, востребованность образовательных услуг, рейтинг высших учебных заведений, мнение потребителей, оценка качества, оценка востребованности

$\mathrm{M}$ ировые тренды и растущая скорость технологических изменений в различных областях определяют будущее образования, т.к. на их основе формируются требования к образованию со стороны потребителей, оценивается, оправдываются ли их ожидания, и определяются показатели образовательного успеха. Наступает эпоха $V U C A$-мира $(V-$ volatile, $U-$ uncertain, $C-$ complex, $A$ - ambiguous) - волатильного, неопределенного, сложного, неоднозначного.

Сложно переоценить важность оценки образовательных услуг высших учебных заведений. Ведь именно студенты могут быть одной из основных движущих сил развития, и самого университета в том числе. Они восприимчивы к изменениям и значительно превосходят по численности административнохозяйственных и научно-педагогических работников (среднее соотношение по России в среднем $1: 12)^{1}$.

Основатель Общества организационного обучения в школе менеджмента $M I T$ Sloan (Cambrige, USA) Питер Сенге также подчеркивает, что «система образования - это институт, который имеет самый большой потенциал по воздействию на будущее»². На форуме Global Education Leaders' Partnership Moscow 2018 организация Global Education Futures ${ }^{3}$ представила доклад о будущем образования в сложном обществе XXI в. «Образование для сложного мира: зачем, чему и как», являющийся продолжением глобального исследования «Навыки будущего. Что нужно знать и уметь в новом сложном мире» 4 .

Рынок образования из года в год показывает стабильный рост. В него «вкла-

1 Егоров А. 2018. Будущее за студентами! Именно они смогут изменить университеты к лучшему. Доступ: https://mel.fm/blog/aleksey-yegorov/41786-budushcheye-za-studentami-imenno-oni-mogutizmenit-universitety-k-luchshemu (проверено 18.09.2018).

2 Доклад «Образование для сложного общества». 2018. Доступ: https://edu2035.org/images/people/ GEF_april26-min.pdf (проверено 18.09.2018).

3 https://edu2035.org (проверено 18.09.2018).

4 Лошкарева Е., Лукша П., Ниненко И., Смагин И., Судаков Д. Доклад «Навыки будущего. Что нужно знать и уметь в новом сложном мире». 2017. Доступ: https://edu2035.org/images/people/ WSdoklad_12_okt_eng-ilovepdf-compressed.pdf (проверено 18.09.2018). 
дываются» и государство, и ведущие коммерческие организации, т.к. производимый высшими учебными заведениями «продукт» является фундаментом технологий и культуры общества ближайших десятилетий. В свою очередь, высшие учебные заведения, с одной стороны, постоянно находятся в тесном кольце выдвигаемых со стороны заинтересованных пользователей требований к качеству оказываемых услуг и новых подходов к их оценке и, следовательно, к их востребованности, а с другой - они серьезно регламентированы требованиями законодательных и подзаконных актов.

Показатели оценки качества и востребованности образовательных услуг высшего учебного заведения включают в себя совокупность характеристик реализации потребностей, степень удовлетворения интересов и полноту реализации полномочий (функций) субъектов образовательных отношений потребителей (заинтересованных групп) в рамках нормативно определенной системы государственных стандартов образования, включающей удовлетворение потребностей физических или юридических лиц, в интересах которых осуществляется образовательная деятельность. Эти потребности выражаются в т.ч. и в установках на трудоустройство выпускников вузов в соответствии с сформированными профессиональными качествами hard skills и soft skills, которые фактически определены в Федеральных государственных образовательных стандартах Российской Федерации, и вакансиями на рынке труда: это усвоение компетенций, обеспечивающих реализацию технологического содержания профессиональной деятельности, операциональных способов (технологий) ее осуществления (преимущественно компетенций, относящихся к hard skills); освоение действий, входящих в состав профессиональной деятельности и связанных с реализацией надпрофессиональных целей и задач (преимущественно компетенций, относящихся к soft skills); присвоение студентом смыслов профессиональной деятельности (осознание профессии как сферы реализации специфических профессиональных и жизненных смыслов), выражающееся в приобретении профессиональной субъектности.

В данной научно-исследовательской работе на основе экспертных оценок рассматривались следующие группы заинтересованных пользователей: студенты, родители студентов, выпускники, преподаватели и администрация высшего учебного заведения, профессиональные сообщества (административный и преподавательский состав других вузов), работодатели, научные сообщества и академические структуры, институты гражданского общества.

Основными средствами фиксации первичных характеристик являются экспертные методы, анкетный опрос и вторичный анализ статистических данных, результатов самообследования, показателей национальных и мировых рейтингов.

Эти средства различаются по характеристикам, целевому предназначению, особенностям диагностики первичных данных. Они объединены в целостную исследовательскую технологию, предполагающую получение полного перечня качественных и количественных показателей, выявление их дублирования, взаимное дополнение, интегрирование по компонентам востребованности и качества и обобщенное рейтинговое значение.

Оценка качества и востребованности образовательных услуг высших учебных заведений с учетом мнения потребителей осуществляется на основании алгоритмизированной модели организационно-технологического характера, включающей общие этапы научного исследования и специфические процедуры выявления конкурентоспособности (рыночной ценности) образовательных организаций. 


\section{Таблица 1}

Основные показатели востребованности и качества образовательных услуг, учитывающие мнение потребителя

\begin{tabular}{|c|c|}
\hline \multicolumn{2}{|c|}{$\begin{array}{c}\text { I группа потребителей: } \\
\text { непосредственные потребители образовательных услуг }\end{array}$} \\
\hline Студенты & $\begin{array}{l}\text { Удовлетворенность: } \\
\text { - содержанием учебного процесса; } \\
\text { - организацией учебного процесса; } \\
\text { - перспективностью получаемых компетенций } \\
\text { (знаний, навыков, умений) с точки зрения возможности } \\
\text { трудоустройства; } \\
\text { - полнотой информации о вузе с точки зрения его } \\
\text { положения в различных рейтингах среди образовательных } \\
\text { организаций }\end{array}$ \\
\hline $\begin{array}{l}\text { Родители } \\
\text { студентов }\end{array}$ & $\begin{array}{l}\text { Удовлетворенность: } \\
\text { - организацией учебного процесса; } \\
\text { - содержанием учебного процесса с точки зрения } \\
\text { практической направленности; } \\
\text { - полнотой информации о вузе с точки зрения его } \\
\text { положения в различных рейтингах среди образовательных } \\
\text { организаций; } \\
\text { - количественные и качественные показатели фактов } \\
\text { обращения в уполномоченные государственные структуры и } \\
\text { общественные организации за помощью в восстановлении } \\
\text { нарушенных прав в сфере образования; } \\
\text { - характеристикой общественного мнения участников } \\
\text { образовательного рынка о вузе с точки зрения соблюдения } \\
\text { прав потребителей; } \\
\text { - уровнем конфликтности во взаимодействии вуза с } \\
\text { участниками отношений в образовательной сфере }\end{array}$ \\
\hline $\begin{array}{l}\text { Работодатели, } \\
\text { осуществляющие заказ } \\
\text { на целевую подготовку } \\
\text { кадров в вузе }\end{array}$ & $\begin{array}{l}\text { - объем заказа (число лиц, направленных на обучение); } \\
\text { - удовлетворенность результатами обучения и стабильность } \\
\text { заказа на подготовку специалистов }\end{array}$ \\
\hline \multicolumn{2}{|r|}{$\begin{array}{l}\text { II группа потребителей: } \\
\text { руководство (администрация) вузов }\end{array}$} \\
\hline $\begin{array}{l}\text { Руководство } \\
\text { (администрация) }\end{array}$ & $\begin{array}{l}\text { - результаты самообследования в части } \\
\text { практикоориентированности, востребованности на рынке; } \\
\text { - показатели рейтингов в части } \\
\text { практикоориентированности, востребованности на рынке }\end{array}$ \\
\hline \multicolumn{2}{|c|}{$\begin{array}{l}\text { III группа потребителей: } \\
\text { субъекты экономической деятельности, хозяйственных отношений }\end{array}$} \\
\hline $\begin{array}{l}\text { Субъекты регионального } \\
\text { и общероссийского } \\
\text { уровня }\end{array}$ & $\begin{array}{l}\text { - оценка востребованности выпускников вуза с точки } \\
\text { зрения трудоустройства в организации; } \\
\text { - оценка профессиональной подготовленности и качества } \\
\text { работы выпускников вуза, осуществляющих трудовую } \\
\text { деятельность; } \\
\text { - удовлетворенность полнотой информации о вузе с } \\
\text { точки зрения его положения в различных рейтингах среди } \\
\text { образовательных организаций }\end{array}$ \\
\hline
\end{tabular}




\begin{tabular}{|c|c|}
\hline $\begin{array}{l}\text { Органы государственного } \\
\text { и муниципального } \\
\text { управления }\end{array}$ & $\begin{array}{l}\text { - количественные показатели трудоустройства в органах } \\
\text { государственного и муниципального управления, } \\
\text { подчиненных структурах; } \\
\text { - оценка профессиональной подготовленности и качества } \\
\text { работы выпускников вуза, осуществляющих трудовую } \\
\text { деятельность в органах государственного и муниципального } \\
\text { управления, подчиненных структурах; } \\
\text { - удовлетворенность полнотой информации о вузе с } \\
\text { точки зрения его положения в различных рейтингах среди } \\
\text { образовательных организаций }\end{array}$ \\
\hline $\begin{array}{l}\text { Субъекты } \\
\text { государственного } \\
\text { и муниципального } \\
\text { управления }\end{array}$ & $\begin{array}{l}\text { - показатели соблюдения нормативов взаимодействия с } \\
\text { участниками образовательных отношений; } \\
\text { - ориентированность на решение региональных задач } \\
\text { насыщения рынка труда; } \\
\text { - удовлетворенность полнотой информации о вузе с } \\
\text { точки зрения его положения в различных рейтингах среди } \\
\text { образовательных организаций }\end{array}$ \\
\hline $\begin{array}{l}\text { Институты } \\
\text { профессионального } \\
\text { сообества в области } \\
\text { регулирования } \\
\text { реализации } \\
\text { профессиональных } \\
\text { стандартов }\end{array}$ & $\begin{array}{l}\text { - уровень реализации в образовательных программах } \\
\text { требований профессиональных стандартов; } \\
\text { - уровень включенности в систему профессионально- } \\
\text { общественной экспертизы; } \\
\text { - удовлетворенность полнотой информации о вузе с } \\
\text { точки зрения его положения в различных рейтингах среди } \\
\text { образовательных организаций }\end{array}$ \\
\hline
\end{tabular}

Этапы сбора первичных данных:

1) определение перечня высших учебных заведений, которые подвергаются оцениванию;

2) осуществление частных исследовательских проектов по экспертной оценке образовательных услуг высших учебных заведений со стороны работодателей, выпускников вузов и по опросам студентов и профессорско-преподавательского состава;

3) вторичный анализ статистических данных и результатов национальных и мировых рейтингов высших учебных заведений, организуемый специализированными агентствами, исследовательскими центрами, аналитическими структурами.

Этапы анализа и обработки данных в целях получения рейтинговой оценки образовательных услуг высших учебных заведений:

1) преобразование и нормирование полученной первичной информации;

2) определение весовых коэффициентов первичных характеристик;

3) агрегирование частных показателей уровня востребованности, качества образовательных услуг;

4) расчет общего показателя рейтинга образовательных услуг вуза.

Включаемые в модель показатели качества образовательных услуг соотнесены с выявленным в ходе экспертной оценки перечнем профессиональных качеств выпускников вузов.

Показатели качества образовательных услуг:

- востребованность выпускников вуза (диплом вуза является конкурентным преимуществом выпускника при приеме на работу);

- профессиональные достижения (портфолио);

- доля выпускников, работающих по профессии в течение 5 лет после завершения образования;

- успешная карьера в течение 5 лет после завершения образования; 
- доля выпускников, создавших основанные на профессиональных компетенциях стартапы (коммерческие предприятия, НКО);

- уровень заработной платы или доходов выпускников в течение 5 лет после завершения образования.

Показатели результатов образования:

- способность к самообразованию (воспроизводству выпускником своей профессиональной субъектности в меняющихся обстоятельствах осуществления профессиональной деятельности);

- способность эффективно, со смыслом и ответственно распоряжаться профессиональными компетенциями в различных профессиональных ситуациях;

- осознание профессиональной чести, ответственности;

- профессиональные знания и компетенции;

- профессиональное мышление;

- освоение основных (связанных с типичными профессиональными практиками) профессиональных ролей;

- восприятие профессии как сферы самореализации, прочные отношения с профессией, «любовь к профессии»;

- приобретение, наряду с навыками hard skills, навыков soft skills;

- стратегическое видение профессии, понимание вызовов времени, глобальных трендов, тенденций;

- умение неординарно (новаторски) подойти к решению профессиональных задач, изобретательность, креативность.

Показатели характеристики образовательного процесса:

- профессорско-преподавательский состав и обслуживающий персонал;

- вовлеченность преподавателей и студентов в научную, проектную, экспертную и пр. деятельность, эффективная организация академической активности;

- финансовые ресурсы;

- материальные ресурсы, помещения, оборудование;

- управление и администрация (планирование, организация и контроль);

- информационные ресурсы (библиотека, компьютеры и другие источники информации);

- ясная и реалистичная система приоритетов и целей образования, в отношении которых существует консенсус профессорско-преподавательского состава, администрации и студентов вуза;

- организация быта, обслуживания студентов и обеспечение условий для образования;

- достаточно высокий уровень независимости вуза в реализации образовательных программ.

Таким образом, оценка востребованности и качества образовательных услуг, предоставляемых вузом, осуществляется на основе специально разработанной методики, модель которой представлена в форме алгоритмизированной модели организационно-технологического характера, включающей общие этапы научного исследования и специфические процедуры выявления конкурентоспособности (рыночной ценности) образовательных организаций.

Статья подготовлена по результатам исследований, выполненных за счет бюджетныхсредств по государственному заданию Финансовому университету. 
RAZOV Pavel Viktorovich, Dr.Sci. (Soc.), Associate Professor; Professor of the Department of Sociology, History and Philosophy, Financial University under the Government of the Russian Federation (49 Leningradsky Ave, Moscow, Russia, 125993;PVRazov@fa.ru)

AMERSLANOVA Aynara Nadirovna, Senior Lecturer of the Department of Accounting, Analysis and Audit; Head of the Department of Development Programs, Financial University under the Government of the Russian Federation (49 Leningradsky Ave, Moscow, Russia, 125993; Aynarana@gmail.com)

\title{
ASSESSMENT OF THE EDUCATIONAL SERVICES QUALITY AND RELEVANCE OF HIGHER EDUCATION INSTITUTIONS, CONSIDERING THE CONSUMERS' OPINIONS
}

Abstract. The article deals with the assessment of demand and quality of educational services provided by universities, based on a specially developed methodology. This technique is presented in the form of an algorithmized model of organizational and technological nature, which includes the general stages of scientific research and specific procedures for identifying the competitiveness (market value) of educational institutions.

Keywords: educational services quality, educational services relevance, ranking of higher education institutions, consumers' opinion, quality assessment, relevance assessment

ПЕШКОВА Вера Михайловна - кандидат исторических наук, старший научный сотрудник Центра региональной социологии и конфликтологии Института социологии Федерального научноисследовательского социологического центра Российской академии наук ФНИСЦ РАН (117218, Россия, г. Москва, ул. Кржижановского, 24/35, корп. 5; pever@таil.ru)

\section{МАТЕРИАЛЬНЫЙ МИР МИГРАНТОВ В КОНТЕКСТЕ ТРАНСНАЦИОНАЛЬНОЙ МИГРАЦИИ В РОССИЮ}

\begin{abstract}
Аннотация. В статье рассматриваются некоторые характеристики материального мира трудовых мигрантов из Средней Азии в Россию. Исходной установкой послужил тезис, что современная миграция является сложным транснациональным феноменом, включающим в себя движение между странами не только людей, но и различных элементов материальной культуры. Транснациональный поток вещей между Россией и странами Средней Азии классифицируется по направлению движения вещей «домой» и «из дома", а также по тому, какие социальные отношения сопровождают это движение и каким смыслом отправитель и получатель наделяют «вещь», например гостинцы/подарки и сувениры, вещи для домашнего обустройства и дары.
\end{abstract}

Ключевые слова: транснациональная миграция, мигранты из Средней Азии, материальный мир, движение вещей

$\mathrm{B}$ зависимости от того, какой аспект материального мира и его взаимодействия с социальностью интересует исследователя, социальное изучение вещей происходит с одной из таких теоретических перспектив, как социология потребления, социология материальности, социальная жизнь вещей, теория социальных практик, теория социального обмена. Данные перспективы в той или иной степени нашли применение при изучении проблем на пересечении мира мигрантов и материальности, под которой понимаются не только физиче- 